\title{
The Lesser Evil: Executive Accountability with Partisan Supporters*
}

\author{
Gerard Padró-i-Miquel \\ London School of Economics \\ and Political Science \\ G.Padro@lse.ac.uk \\ econ.lse.ac.uk/staff/padroimiquel_gerard/
}

\author{
Erik Snowberg \\ California Institute of Technology \\ snowberg@caltech.edu \\ www.hss.caltech.edu/ $\sim_{\text {snowberg }}$
}

April 20, 2010

\begin{abstract}
We develop a model of electoral accountability with primaries. Prior to the general election, the supporters of each of two parties decide which candidates to nominate. We show that supporters suffer from a fundamental tension: while they want politicians who will faithfully implement the party's agenda in office, they need politicians who can win elections. Accountability to supporters fails when supporters fear that by punishing or rewarding their incumbent for her loyalty or lack thereof, they unintendedly increase the electoral prospects of the opposing party. Therefore, accountability decreases with the importance that supporters assign to the elections, and it breaks down in two cases. First, a popular incumbent safely defects as she knows she will be re-nominated. Second, an unpopular incumbent defects because she knows she will be dismissed even if she follows the party line. These behaviors are labeled impunity and damnation respectively, and are illustrated with case studies.
\end{abstract}

${ }^{*}$ We thank Brandice Canes-Wrone, David Karol, Keith Krehbiel, Ken Shotts and Jean-Laurent Rosenthal and seminar participants at UCLA, the University of Essex, IMT Lucca and Berkeley for useful comments and conversations. 


\section{Introduction}

Then he set out the criteria for choosing the new leader:

Who would maximize support for the party in the country? Who will play best at the box office, who will not simply appeal to the traditional party supporters and customers of the Labour Party, but who will bring in those extra, additional voters that we need in order to win convincingly at the next election?

-Peter Mandelson, quoted in Rentoul (2001, p.

What are you going to do grandma? We're at war. What are you going to do, vote for Kucinich?

-David Cross, channeling George W. Bush

On August 22nd, 1996, Bill Clinton defied leaders of the Democratic party by signing into law the Personal Responsibility and Work Opportunity Reconciliation Act, a Republican welfare reform bill. A week later, there wasn't a whiff of protest at the Democratic convention that re-nominated Clinton, despite the general opposition of Democrats to the law. Clinton's flouting of his party wasn't the first or last time an American executive took an action that was deeply unpopular in his party. To pick a few of the numerous examples: Nixon went to China, Johnson escalated the Vietnam war, and Hayes and Arthur championed civilservice reform. Moreover, the U.S. does not have a monopoly on politicians disregarding their parties. To wit: Tony Blair (UK) and José Maria Aznar (Spain) dispatched troops in the second Iraq war, and Felipe González (Spain) implemented labor market reforms over the fierce opposition of their respective parties and supporters.

To understand why politicians are able to defy their parties and remain in power, consider the predicament of a Democrat in 1996. He or she could punish Clinton for his defection from the party line by trying to deny him re-nomination. However, given Clinton's popularity among unaffiliated voters, his replacement would be more likely to lose the general election. In short, a supporter had to choose between two evils: an incumbent who revealed he was not loyal to the party line, and a higher probability of a Republican president. This situation illustrates the fundamental tension between politicians and their supporters: supporters 
want politicians who will faithfully implement the party's agenda while in office, but they also need politicians who win elections ${ }^{1}$ In practice, this tension often restrains supporters from punishing politicians who have defected from the party line. For example, even though two of Clinton's senior advisors resigned over his signing of welfare reform, they put off their resignations until after the Democratic convention so as not to compromise Clinton's re-nomination. In the words of one of them, "I did want to see President Clinton re-elected." (Edelman, 1997)

In light of this fundamental tension, we identify conditions under which an incumbent politician will strategically take decisions congruent with the preferences of supporters and when, conversely, she will be able to follow her own agenda on a subset of issues, as Clinton did on welfare reform. Specifically, we develop a game-theoretic electoral accountability model where an incumbent politician can decide to implement her own agenda against the wishes of her supporters. After this publicly observed decision, party supporters choose whether to retain the incumbent, or jettison her in favor of a challenger. The candidate that emerges faces a candidate from the opposite party in a general election. Party supporters thus have conflicting goals: they want to both discipline the incumbent and win the general election. Knowledge of this conflict informs the decision of the incumbent and determines her willingness to follow the party line.

There are four main contributions of the theory analyzed here. First, we show that politicians who are popular enough with unaffiliated voters can safely defect from the party line and still secure re-nomination. This occurs because the difficulty of finding an alternative candidate of similarly high-valence imposes an implicit cost on party supporters: punishing defections is associated with a lower probability of victory in the general election. Knowing this, a charismatic incumbent defects with impunity.

Second, and less intuitive, a similar lack of accountability also occurs with low valence incumbents. This occurs because a party cannot commit to re-nominate the incumbent if

\footnotetext{
${ }^{1}$ The literature on the dynamics of primaries contains some discussion of the tradeoff between electability and policy (see, e.g. Aldrich, 1980, Chapter 4). We believe we are the first to model this tradeoff formally.
} 
there is a replacement candidate that is expected to perform much better in the general election. Consequently, the incumbent has no incentive to follow supporters' directives while in office, and will follow her own agenda. This behavior is called damnation.

Third, the importance supporters place on winning the general election exacerbates failings of accountability. The importance of elections varies due to several different factors. For instance, in a situation where several Supreme Court judges are expected to vacate their posts, both conservatives and liberals will place a large premium on having a President from their respective party in power $2^{2}$ Similarly, importance will generally be large when the parties are highly polarized (McCarty, Poole and Rosenthal, 2006). In these situations, the prospect of losing to the other party is particularly dire, and supporters put greater weight on winning than on ensuring loyalty. Thus, both impunity and damnation are more common when the stakes from winning are perceived to be high.

The analysis reveals that as victory becomes more important to supporters, it damages their ability to control both high- and low-valence politicians. In contrast, valence has a nonmonotonic effect on accountability. For a fixed level of importance, high- and low- valence incumbents will defy their supporters (for different reasons) while incumbents with average electoral appeal will remain loyal to the party line.

Our fourth contribution is more technical. The literature on electoral accountability and executive decision-making considers the relationship between an incumbent and a representative citizen $]^{3}$ In addition, it is a common feature of this literature that the representative citizen either cannot observe the actions of politicians, or ignores whether these actions are ultimately taken for his or her own good. Our framework adds to this literature in three respects. First, by introducing party supporters, we allow for the existence of different types

\footnotetext{
${ }^{2}$ For example, Clinton's appointees to the Supreme Court, Ginsberg and Breyer, are two of the most consistently liberal justices today. Moreover, they were appointed when one more conservative justice would have lead to the overturning of Roe v. Wade.

${ }^{3}$ The large literature on electoral accountability focuses on the extent to which voters can discipline politicians (Riker, 1982), and on the ability of voters to select competent policy-makers. See Ferejohn (1986); Austen-Smith and Banks (1989); Rogoff (1990); Banks and Sundaram (1993); Fearon (1999); Besley (2006); Snyder and Ting (2008) among many others. Formal theories of executive decision making add asymmetric information about the appropriate policy to choose. See, for instance, Canes-Wrone, Herron and Shotts (2001); Maskin and Tirole (2004); Prat (2005); Fox and Shotts (2009).
} 
of voters. Second, we add a nomination process for candidates in which supporters participate. These modifications shift the emphasis from accountability to a representative citizen to accountability to party supporters. This shift has important implications as an incumbent must be re-nominated before she can be held accountable by the electorate at large. Third, in our model, party supporters know exactly when the politician has defected from the party line. In previous models, without uncertainty over an incumbent's actions or their consequences, disciplining politicians is trivial. However, as the Clinton example shows, there are many situations in which open defections to the party line go unpunished, and our model provides a potential explanation.4 These elements together illuminate the role of valence and the importance of victory to supporters in executive decision-making.

We also contribute to the small formal literature on intra-party politics and the role of primaries (see, e.g., Cooper and Munger, 2000 and Serra, 2007) as well as the literature on policy competition and valence (see Ansolabehere and Snyder (2000); Groseclose (2001); Aragones and Palfrey (2004); Serra (2009)). Touching on both issues, Hirano, Snyder and Ting (2009) add primaries to a model of distributive politics and find that as polarization increases, candidates promise less spending to core supporters. This finding resonates with one of ours. However, the mechanism is quite different. In particular, Hirano, Snyder and Ting (2009) follows the rest of the electoral competition literature in assuming candidates pre-commit to platforms, thus ruling out defections. As a consequence, previous models cannot shed light on when party lines will be followed or flouted.

\subsection{Definition of Conceptual Terms}

Since we add several new elements to the formal literature on accountability and executive decision-making, it is important to be precise about our use of certain terms. Specifically: parties and the party line, election importance, valence, and defection.

A party is defined as a group of agents who control the process of putting forward a

\footnotetext{
${ }^{4}$ Our mechanism is related to that of Padró i Miquel (2007) which considers the role of fear in ethnic politics in developing countries.
} 
candidate for a general election. These agents are assumed to have extremely similar or identical preferences. Thus, the concept of party adopted here is similar to the concept in Cohen et al. (2008), which is supported therein by extensive empirical research. Some scholars assert that parties exhibit significant heterogeneity of preferences, and little control of the nominating process. These realistic factors will only exacerbate the accountability failures identified here. By assuming that party supporters are homogeneous, we are stacking the deck in favor of accountability in order to isolate the sources of failure.

As party supporters are assumed to be homogenous, the party line is then easily conceptualized as the preferences of these homogeneous agents on each possible issue. For this reason, we use the terms party, party members and supporters interchangeably. Throughout the article, the terms accountability to the party, accountability to supporters, and party control of politicians will also be used synonymously.

The importance of an election is defined as the difference in utility that a party member obtains when his party is in power, versus what he obtains when the other party is in power. Importance is high in situations in which the two party lines are distant from each other. This occurs, for instance, when there is high polarization, when pork can be easily targeted to supporters, or when the victor will make decisions with long-term consequences.

Valence captures candidate attributes such as charisma, character and competence that makes her popular among unaffiliated voters $5^{5}$ For a given set of candidate preferences, an increase in these attributes increases the probability that a candidate will appeal to voters and win a general election.

Valence and importance both vary, but do so in different ways. Some politicians are clearly much better than others at winning elections: Clinton was often hailed for his charisma and ability to frame issues in a way that favored his position. Hence, in our formulation, valence is a personal attribute of a particular politician. In contrast, importance is an attribute of the political environment and the decisions the incumbent is expected to face, and thus varies over time, as a function of political circumstances (see, e.g. McCarty,

\footnotetext{
${ }^{5}$ For more discussion of valence see Groseclose $[2001)$.
} 
Poole and Rosenthal, 2006).

An incumbent defects when she disregards the party line and implements her own agenda. This results in lower utility for supporters. The effect on the utility of members of other parties, and on unaffiliated voters, is less clear. For example, if the incumbent implements a more centrist policy agenda than that preferred by her party, such as Clinton's approval of welfare reform, this may benefit members of other parties and centrist voters. Instead, the incumbent might implement a policy that nobody in the electorate favors, such as Aznar's decision to send Spanish troops to the second Iraq war. In this case, the deviation would hurt members of both parties, and unaffiliated voters. Finally, there are policies in which the preferences of swing voters and supporters of the other party are not clearly affected. For example, when Blair decided to send British troops to the second Iraq war, the Conservative party was mildly in support and all the strong-worded opposition came from within Labour ranks. Our main results are similar under any of these three interpretations. However, to focus squarely on the accountability of politicians to their supporters, we adopt the final formulation - i.e. the incumbent's deviations reduce supporter utility and do not affect swing voters or opposite party supporters. The case where defection makes the incumbent more attractive to non-party voters is discussed in Section 4.1 .

\section{A Model of Party Control of Politicians}

This section mathematically formalizes the above definitions. We study a two-period model. The incumbent must stand for re-election after the first period, and thus can be denied renomination by her supporters if she deviates from the party line. The players are politicians, party supporters, and unaffiliated voters. We use female pronouns for politicians and male pronouns for voters throughout. 


\section{$2.1 \quad$ Politicians}

There are three different politicians, labelled $i \in\{I, C, R\}$ for incumbent, challenger and rival, from two different parties. The incumbent is in office at the beginning of the game. The challenger is from the same party as the incumbent. The incumbent and challenger's party supporters decide which of them will face the politician from the rival party in the general election. Each politician is described by two attributes: her valence $v_{i} \in[0, \bar{v}]$ and her type $\theta_{i} \in\{O, L\}$.

The incumbent's valence is common knowledge to all players and captures her personal electoral appeal to unaffiliated voters. To compare our results with the basic electoral accountability framework, we delay the description of the effect of valence.

A politician's type $\theta_{i} \in\{O, L\}$ captures whether her personal agenda overlaps perfectly with her party's. This is privately known to the politician at the beginning of the game. From the point of view of party supporters, politicians have a prior probability $\pi_{i}$ of being a loyalist $\theta_{i}=L$ whose personal agenda is perfectly aligned with her party. With prior probability $1-\pi_{i}$, however, a politician may be an opportunist $\theta_{i}=O$ whose personal agenda is different from the party's in some ways. Another interpretation is that supporters are aware of each politician's preferences, but don't know the politician's ability to override the party and successfully implement her own agenda, possibly because of uncertainty about the future political environment. As the incumbent was once a challenger, each candidate has an equal probability of being a loyalist from the party's point of view before they are elected. That is, $\pi_{I}=\pi_{C}=\pi_{R}$. In Section 4.2 we examine the case where $\pi_{I}>\pi_{C}$.

Both types receive the same utility, normalized to one, from the ego-rents of office and implementing their preferred agenda. As the opportunist's preferred agenda is different from that of party supporters, she suffers a cost of $\eta \in(0,1)$ if she toes the party line. Loyalists would also suffer a cost from implementing something other than their most preferred agenda. However, loyalists agree perfectly with party supporters and will thus always implement the 
party's agenda. Politician utility is thus given by:

$$
u_{i}= \begin{cases}\mathbb{I}_{\{i \text { in office }\}}\left(1-\eta \mathbb{I}_{\{i \text { party line }\}}\right) & \text { if } \theta_{i}=O \\ \mathbb{I}_{\{i \text { in office }\}} & \text { if } \theta_{i}=L\end{cases}
$$

where $\mathbb{I}_{\{i \text { in office }\}}$ and $\mathbb{I}_{\{i \text { party line }\}}$ are indicator functions. The first takes a value of one if the politician is in office and zero otherwise. The second takes a value of one if an opportunist implements the party line. Equivalently, the opportunist's utility function can be interpreted as the opportunist receiving a benefit of $\eta$ if she defects from the party line to implement her own agenda. Under both interpretations, $\eta$ parameterizes the opportunist's relative value of implementing her preferred agenda to ego-rents from holding office.

\subsection{Party Supporters}

As discussed above, to focus on accountability to the party, we model a situation in which an incumbent's defection from the party line only harms the incumbent's supporters and has no effect on other players. We consider the case where defections benefit unaffiliated voters in Section 4.1. Party supporter utility is given by:

$$
u_{p}=\mathbb{I}_{\{p \text { in office }\}}\left(\lambda-\mathbb{I}_{\{i \text { defects }\}}\right)
$$

where $\mathbb{I}_{\{p \text { in office }\}}$ takes a value of one if a politician from the supporters' party is in office, and zero otherwise, and $\mathbb{I}_{\{i \text { defects }\}}=1-\mathbb{I}_{\{i \text { party line }\}}$ takes a value of one if the politician in office implements her own agenda, rather than the party's. Thus, $\lambda$ parameterizes the relative value to party supporters of having one of their own in office to the costs of incumbent defection. This is naturally interpreted as the importance of an election to supporters.

Even if the incumbent defects on some subset of issues, the incumbent party still prefers to have one of their own in power. Party members will be appointed to head executive agencies, and many lower positions. In addition, the U.S. President makes lifetime appointments to the federal bench. By picking judges that primarily agree with the party's ideology, she 
ensures a long stream of benefits for party members. While some of the politician's policies may not be the party's liking, her policies in a majority of areas are better for her party than supporters could hope for under the opposition. To ensure that the party always prefers a politician of average loyalty from its own ranks in power, we assume that $\lambda>1-\pi_{I}=1-\pi_{C}$.

After observing whether or not the incumbent defected, her party decides whether to renominate her, or replace her with the challenger. Removing the incumbent has no direct cost to supporters, and thus provides the incumbent politician with an incentive to toe the party line in the first policy period $!^{6}$ If the incumbent party chooses to remove the incumbent, the challenger will face the opposition in the forthcoming general elections.

To summarize, the timeline of the game is as follows:

1. (First Policy Period) The incumbent decides whether or not to defect.

2. (Re-nomination) The incumbent's party decides whether to re-nominate the incumbent or costlessly switch to the challenger.

3. (Election) Unaffiliated voters decide between the rival candidate and the incumbent or challenger (depending on the party's decision at stage 2).

4. (Second Policy Period) The elected politician decides whether or not to defect.

The game ends after the second policy period, so, if an opportunist is in office in this period, she will always implement her personal agenda. Thus, we focus on whether or not party supporters can prevent an opportunist incumbent from defecting in the first policy period.

A more complete description of how unaffiliated voters choose a candidate in the election is postponed briefly. For now, assume either of the party's candidates (the incumbent or the challenger) is elected with some exogenous probability $\Gamma_{I} \in[0,1]$ if she is nominated. This is a familiar setting where the opportunist incumbent will be fully accountable to her party as

\footnotetext{
${ }^{6}$ While there are many mechanisms that parties use to discipline politicians, see e.g. Bowler, Farrell and Katz (1999), we follow Mayhew (1974) in thinking of politicians as "single-minded seekers of re-election." Thus, all discipline must be carried out through decreasing a politician's probability of re-election. Failing to re-nominate an incumbent is just an extreme form of this.
} 
long as the reward of being re-elected (and defecting in the second policy period) is greater than the temptation of defecting in the first policy period. As the value of re-nomination to the opportunist is $\Gamma_{I}$, and the value of defecting in the first policy period is $\eta$, the incumbent will not defect when $\Gamma_{I}>\eta$. This equilibrium is illustrated in Figure 1 .

Proposition 1 In equilibrium, the incumbent is fully accountable to her party if and only if $\Gamma_{I}>\eta$

The logic here is similar to the seminal electoral accountability models of Barro (1973) and Ferejohn (1986). When $\Gamma_{I}<\eta$, an opportunist incumbent always defects from the party line as the immediate reward is better than the promise of re-nomination. We label this region temptation, and it will figure in the equilibrium of the full model. Here, when $\Gamma_{I}>\eta$ the incumbent is fully accountable to her party. However, we will show that once valence is added, there are large portions of the parameter space where the above condition is satisfied, but the party is unable to control the incumbent.

\subsection{Unaffiliated Voters and Valence}

As in this model politicians cannot commit to platforms, unaffiliated voters decide which candidate to elect based on the valence of both candidates. In other words, these voters are indifferent between parties and therefore choose according to candidate characteristics. As noted above, in order to focus on the control of politicians by their parties, we consider a situation in which unaffiliated voters are unconcerned with whether or not a politician defects from their party line. However, if the incumbent's first period action is interpreted as a policy, this assumption may be too stark. Therefore, we examine this case in detail in Section 4.1 and show the qualitative results do not change.

We model unaffiliated voters' choice in a simple, but general, way. Given two candidates $i$ and $j$ with valence $v_{i}$ and $v_{j}$ respectively, candidate $i$ will win the election with probability $\gamma\left(v_{i}, v_{j}\right)$ where $\gamma(\cdot)$ is non-decreasing in its first argument, and non-increasing in its second argument. In addition, for any $v_{i}$ there exists a $v_{j}$ such that $\gamma\left(v_{i}, v_{j}\right)$ is strictly increasing 
in the first argument. Simply put, this means that as a politician's valence increases, there is some increase in her electoral prospects. This captures a wide range of potential electoral models - from a simple model where the candidate with the highest valence almost always wins to probabilistic voting models.

If the party removes the incumbent, she is replaced by the untested challenger. The challenger's valence is therefore perceived as a random draw from a distribution with c.d.f. $F_{C}$, and the rival's valence is a random draw from a distribution with c.d.f. $F_{R}$. Both of these distributions are assumed to be continuous with full support on $[0, \bar{v}]$.

Given the incumbent's valence $v_{I}$ (which is common knowledge), the incumbent will win re-election if re-nominated, with probability

$$
\Gamma_{I}\left(v_{I}\right)=\int_{0}^{\bar{v}} \gamma\left(v_{I}, v_{R}\right) d F_{R}\left(v_{R}\right)
$$

whereas if the incumbent is removed from office, the challenger will win with probability

$$
E\left(\Gamma_{C}\right)=\int_{0}^{\bar{v}} \Gamma_{I}\left(v_{C}\right) d F_{C}\left(v_{C}\right)
$$

Note that the assumptions on $\gamma(\cdot)$ and $F_{R}$ are sufficient for $\Gamma_{I}\left(v_{I}\right)$ to be continuous and strictly increasing in $v_{I}$. Note also that $E\left(\Gamma_{C}\right)$ is just a constant that does not depend on the specific value of the incumbent's valence $v_{I}$. For simplicity we suppress the dependence on $v_{I}$ and refer to an increase in $\Gamma_{I}$ as an increase in incumbent valence.

The sequence of the game remains the same as before. Any draws of candidate valence happen simultaneously after the incumbent party decides whether or not to re-nominate the incumbent, but before unaffiliated voters elect a candidate. Thus, valence is common knowledge at the time of the general election.

Note that the incumbent's valence is known, while the challenger's and rival's valences are not, at the time of the re-nomination decision. This formulation is appealing as the incumbent has already won a general election, while the challenger and rival are untested. 
However, due to risk neutrality, nothing in the results below hinges on the fact that $v_{C}$ and $v_{R}$ are unknown when the party makes its decision. Specifically, if $\Gamma_{I}$ is the probability that the incumbent will beat a rival candidate with known valence, and $E\left(\Gamma_{C}\right)$ is the probability a challenger with known valence will beat a rival candidate with known valence, all of the below results would go through.

\section{Results}

\subsection{Equilibrium Characterization}

Equilibrium behavior depends on the importance of the election $\lambda$, the probability the incumbent is re-elected given that she is re-nominated $\Gamma_{I}$ (which depends on the incumbent's valence), and how much politicians value implementing their personal agenda versus the ego rents from holding office $\eta$. Before characterizing the equilibrium, we establish that it is unique.

Proposition 2 (Uniqueness) There exists a unique perfect-bayesian equilibrium.

The main object of interest is whether or not the incumbent is accountable - that is, whether an opportunist incumbent toes the party line. It is obvious that loyalist incumbents never defect from the party line: they have nothing to gain by doing so and would risk removal by their party. Opportunists, on the other hand, face a dilemma. If they defect in the first period, they obtain higher personal utility. However, this might cause the party to remove them, forfeiting both the ego-rents and the payoff $\eta$ of implementing their personal agenda in the second period. Supporters also face a dilemma when considering re-nomination. If the incumbent defects in the first period, the party knows she is an opportunist that will defect in the second period if given the chance. However, an opportunist's valence alone may warrant re-nomination over an untested challenger with a greater probability of being a loyalist. Which option is the lesser evil determines supporters' decisions. 
The tensions between these incentives determine when opportunist incumbents are accountable to the party. Within the equilibrium, there are five different behavioral regions for opportunists, as illustrated in Figure 2 and described below.

As in the model without valence, when $\eta$ is larger than the probability that the incumbent will be re-elected if re-nominated, $\Gamma_{I}$, an opportunist will be tempted and defect in the first period even if toeing the party line would secure re-nomination. Intuitively, the highest reward supporters can promise is re-nomination, and this might not be very valuable due to the politician's probability of losing the general election. As before, this behavior is called temptation.

Temptation: If the incumbent's chance of re-election upon re-nomination $\Gamma_{I}$ is too low, then even if she were guaranteed re-nomination, she would prefer the reward $\eta$ of implementing her personal agenda now even if this results in removal by her party. This occurs, as in the basic model, whenever $\Gamma_{I}<\eta$.

Note that in this region supporters cannot do anything to avoid defection. To emphasize the changes due to the introduction of valence into the framework, we assume $\eta<E\left(\Gamma_{C}\right)$, which guarantees the temptation region is small enough to not obscure any interesting predictions.

We now examine the rest of the parameter space where the model without valence predicts that incumbents are completely accountable to the party. The discussion can be divided into four rough quadrants. These are where the incumbent's valence is either high or low with respect to the challenger, and where importance of the forthcoming election is high or low.

With a high-valence incumbent, i.e. $\Gamma_{I}>E\left(\Gamma_{C}\right)$, equilibrium behavior can be divided into two areas depending on the election's importance:

Impunity: When the general election is very important, the benefit of having any party politician in office outweighs the cost of an opportunist defecting. Party supporters will be willing to re-nominate a known opportunist if she has a high enough probability of reelection. Thus, an opportunist incumbent will defect and not suffer any consequences: 
the party will always re-nominate her.

Full Accountability: When an election is not as important, supporters place a high relative value on having a loyalist in office. As such, the incumbent's party is willing to deny re-nomination to a revealed opportunist. An opportunist incumbent deduces the party's response to defection, and will toe the line in the first policy period so that she can capture both ego rents and defect in the second policy period. The incumbent party will re-nominate the incumbent if she does not defect in the first policy period.

The border between these areas is where supporters are indifferent between re-nominating a high-valence opportunist (and therefore securing a high probability of staying in power) and replacing her with a lower-valence challenger who has a positive probability of being a loyalist. As an election becomes more important, the party places a higher value on even small increases in the probability of winning. Thus, this border is downward sloping in Figure 2. Moreover, an increase in the probability the challenger is a loyalist $\pi_{C}$ makes her a more attractive replacement for an opportunist incumbent. This makes the party's threat to remove a misbehaving incumbent credible in some cases, which pushes the border up.

When the incumbent's probability of re-election is lower than the challenger's $\Gamma_{I}<E\left(\Gamma_{C}\right)$, then dismissing the incumbent results in an expected increase in the probability of election for the party in power. However, if the party believes the incumbent is a loyalist, they may be willing to re-nominate her to avoid the possibility that the challenger might defect in the second period. How this tradeoff is resolved depends on the importance of the election.

Partial Accountability: If the election is not very important, then party supporters are willing to trade a lower probability of re-election for a higher probability of having a loyalist in office. Opportunists will thus have an incentive to increase the perceived probability they are loyalists by not defecting. However, if opportunists never defect then the probability the incumbent is loyal will be the same before and after the first policy period. Therefore, the incumbent would always be denied re-nomination, killing 
any incentive to toe the party line $!^{7}$ Thus, in equilibrium, opportunists must defect occasionally, and incumbents that toe the party line must occasionally be cast aside.

As the equilibrium probability of defecting increases, not defecting becomes a stronger signal that the incumbent is a loyalist. The probability opportunists do not defect is thus increasing in the incumbent's probability of re-election, or valence.

In order to keep the incumbent indifferent between defecting and not, a lower probability of re-election must be offset by a higher probability of re-nomination. Therefore in this region, contrary to intuition, the probability that an incumbent that does not defect is re-nominated is decreasing in the incumbent's probability of re-election, or valence.

Damnation: When the election is important, the incumbent party cares only about staying in office. As the incumbent has a lower probability of (re)election than the challenger (in expectation) the party will always remove the incumbent, even if she perfectly implements the party agenda. Knowing this, opportunist incumbents always defect.

Interestingly, in the damnation region, loyalists will make their type known by not defecting. However, the benefit of having a known loyalist in office is not enough to outweigh the decrease in expected election probability that would result from re-nominating the incumbent. Indeed, the border that separates these two regions is where the party is indifferent between an untested challenger that has higher-valence but may be an opportunist, and a known low-valence loyalist. As the importance of the election increases, increasing the probability of electoral victory becomes more urgent for the party, thus the level of valence needed for re-nomination of a known loyalist is higher. For this reason, the border is upward sloping. Conversely, if the challenger is less likely to be a loyalist - that is, $\pi_{C}$ decreases - then she is a less attractive replacement, which will push the border lower.

\footnotetext{
${ }^{7}$ This is straightforward to verify using Bayes' rule. If loyalists never defect, and opportunists defect with probability $\delta$, then the posterior probability the incumbent is a loyalist is equal to $\frac{\pi_{i}}{\left(1-\pi_{i}\right)(1-\delta)+\pi_{i}}$ which is equal to $\pi_{i}$ when $\delta=0$.
} 


\subsection{Comparative Statics}

We now turn to the main question of the paper: how do valence and election importance affect the ability of parties to control their politicians? We define accountability to the party $\alpha$ as the probability that an opportunist incumbent does not defect.

Proposition 3 (Polarization and Accountability) Incumbent accountability to the party $\alpha$ is non-increasing in importance $\lambda$.

As $\Gamma_{I}$ varies there are three regions of behavior, two of which are illustrated in Figure 3 . When $\Gamma_{I}<\eta$ increasing importance $\lambda$ leads from temptation to damnation. In both of these regions, opportunists defect, and the party always removes them. Throughout this region, the incumbent is never accountable to his party, $\alpha=0$.

When $\Gamma_{I}>E\left(\Gamma_{C}\right)$ then increasing importance changes behavior from full accountability to impunity, as illustrated in Panel A of Figure 3. Accountability discontinuously drops from one to zero at the border between these regions. Increasing importance means the party cares more about winning the next election than it does about whether or not their politician is an opportunist who will defect in the second and final policy period. The incumbent politician knows this, and when the election is important enough that the party will re-nominate a known opportunist, the incumbent defects with impunity.

Panel B of Figure 3 illustrates the case when the incumbent has a lower probability of election than the challenger $\Gamma_{I}<E\left(\Gamma_{C}\right)$. When importance is low, the incumbent party is willing to accept a lower probability of re-election in exchange for a higher probability that the candidate they put forward is a loyalist. As the election becomes more important, this tradeoff increasingly favors removing the incumbent to increase the probability a party candidate is elected. When importance is high enough that party supporters will remove even a known loyalist, accountability to the party drops to zero. Knowing she is damned to the dustbin of history, an opportunist always defects.

Proposition 4 (Valence and Accountability) When an election is not particularly important, $\lambda$ is low, accountability to the party is non-decreasing in valence $v_{I}$. When an election 
is important, accountability to the party is non-monotonic in valence.

As importance $\lambda$ varies there are two regions of qualitatively different behavior. When an election is not particularly important, as illustrated in Panel A of Figure 4 , increasing valence moves from damnation, through partial accountability, to full accountability. Increasing valence increases the politician's probability of re-election, and thus the party is willing to re-nominate the incumbent in situations where they would be unwilling to if she had lower valence. Anticipating this, the incumbent will not defect.

When an election is very important, as illustrated in Panel B of Figure 4 , behavior is much the same as when importance is low. As incumbent valence increases, so does accountability to the party, until valence is quite high. At this point, the incumbent knows she will be re-nominated no matter what, and defects with impunity.

This panel illustrates the symmetry of the damnation and impunity regions. In both regions, the party cares more about keeping power than about the probability their candidate is a loyalist. In damnation, the incumbent's probability of re-election is too low to consider re-nominating her, whereas in impunity, the incumbent's probability of re-election is too high to consider removing her. Knowing that her fate does not depend on her behavior, the incumbent will always maximize her own payoff by defecting.

The previous discussion largely ignored the possibility that parameter values may be in the temptation region. This does not change the proposition, but decreases accountability to the party when importance is low.

\section{Extensions}

\subsection{Defection Increases Appeal to Centrist Voters}

If incumbent defection makes her more attractive to centrist voters, this will decrease the ability of the party to control the incumbent, but will make few changes to the qualitative structure of the equilibrium. Specifically, the impunity region will grow to cover parts of 
potentially all of the other regions.

Much of the model remains as before, except that now, when the incumbent politician defects, her valence increases.Due to the assumptions made on the contest function $\gamma\left(v_{i}, v_{j}\right)$ in Section 2.3, this will increase the probability $\Gamma_{I}$ the incumbent will be re-elected if re-nominated by an amount $\Delta \Gamma_{I}>0$ that will depend both on the initial value of the incumbent's valence as well as the increase associated with their defection. For the purposes of illustration, in Figure 5 we assume the function $\Delta \Gamma_{I}$ is relatively smooth in $\Gamma_{I} 8^{8}$

Proposition 5 If defection increases the incumbent's probability of re-election, the incumbent will be less accountable to her supporters.

As shown in Figure 5 (when compared with Figure 2) this modification will increase the size of the impunity region. Indeed, this modification may potentially affect the equilibrium in parts of all the other regions. For instance, consider an opportunist incumbent with valence such that her behavior was previously in the full accountability region. If defection now increases her valence such that the party will wish to retain her even if it knows she is an opportunist, she will now defect with impunity. The same logic applies if the incumbent was previously partially accountable and would have chosen to toe the party line.

Why does this modification not increase the area where party control is possible? The reason is that if the incumbent were previously in temptation or damnation (or was partially accountable, but had decided to defect) then the increase in electability only occurs when the incumbent defects. So even if after a defection the incumbent's probability of re-election $\Gamma_{I}+\Delta \Gamma_{I}$ was high enough so that she would be in the accountability area, she has already defected, and even in full accountability, defectors are not re-nominated. Thus, a candidate in these regions may find herself in a catch-22. The only way to have a probability of reelection high enough to be re-nominated is to defect, but once she defects, she will not be re-nominated. Thus, incumbents in the temptation and damnation areas will continue to

\footnotetext{
${ }^{8}$ If the function $\Delta \Gamma_{I}$ is non-monotonic or discontinuous, the boundary between the impunity and other regions will become jagged, but will always be lower than the boundary when defection does not increase valence.
} 
defect, but will only be re-nominated if $\Gamma_{I}+\Delta \Gamma_{I}$ is high enough so that they are now in the impunity region.

\subsection{The Incumbent as a Party Loyalist}

If supporters previously observed the incumbent's behavior in another office or party post they may believe that she has a higher probability of being a loyalist than the challenger, that is $\pi_{I}>\pi_{C}$. One might expect that this would give the incumbent greater ability to defect from the party line. However, this turns out to benefit the party, as the incumbent will be fully accountable for some parameters where she was only partially accountable when $\pi_{I}=\pi_{C}$

Proposition 6 If the incumbent has a higher a priori probability $\pi_{I}>\pi_{C}$ of being a Loyalist, then she will be more accountable to the party.

The change in equilibrium behavior is illustrated in Figure 6. As can be seen from comparing Figures 2 and 6, part of the partial accountability region becomes part of the full accountability region. This is the part of the parameter space where the party was willing to re-nominate a lower valence incumbent if she had a higher probability of being a loyalist. Previously, the only way for the incumbent to raise her posterior probability of being a loyalist was to only occasionally imitate one. Now the probability the incumbent is a loyalist is exogenously higher, so she can always act like a loyalist and be re-nominated. An illustration of the equilibrium when $\pi_{I}>\pi_{C}$ can be found with proofs of the propositions.

Note there is no change to the impunity region, as this is the set of parameters where the party prefers a known opportunist to the untested challenger. This tradeoff depends on the electability of the incumbent (but not her probability of being a loyalist, which ex-post is known to be zero) versus the expected electability and loyalty of the challenger. As we have not changed the probability that the challenger is loyal in this subsection (it is still given by $\left.\pi_{C}\right)$, the impunity region is unchanged. 


\subsection{The Incumbent as a Partisan}

What if the incumbent was policy motivated? Specifically, assume that in the second policy period, if the incumbent is removed from office or fails to be re-elected, she receives the same utility as any other party supporter 9 That is, if the incumbent is not in office in the second policy period, she still receives positive utility $\nu \in(0,1)$ if a member of her party is in office, and zero otherwise.

This modification changes the equilibrium very little, and does nothing to improve the accountability of the incumbent to the party. In fact, it may make incumbents more likely to defect in the first policy period. Consider an incumbent in the partial accountability region of the original game. The incumbent's probability of re-election (conditional on re-nomination) is less than that of her expected replacement, $\Gamma_{I}<E\left(\Gamma_{C}\right)$. The incumbent would like her party to win even if she is not on the ticket, so she is now more likely to defect and be removed by her party in order to increases the probability that a member of her party is in office in the second period.

This change does not affect the incentives of the incumbent party, so the rest of the equilibrium is unaffected. Incumbents in the impunity region still defect and are re-nominated.

\subsection{Selecting the Heir Apparent}

Bill Clinton was a charismatic retail politician. His Vice-President and heir apparent, Al Gore, was anything but-he was often described as wooden and out-of-touch. While a full treatment of the selection of an heir apparent, or probable challenger, is beyond the scope of this paper, our model can be used to gain some insight into why a charismatic opportunist would want a low-charisma politician as his likely successor.

In the framework of the model, having a low charisma heir apparent is the same as a decrease in $E\left(\Gamma_{C}\right)$, the probability that the expected challenger will be able to defeat the opposition. For a high-charisma (high-valence) incumbent, the most obvious change in the

\footnotetext{
${ }^{9}$ All that matters for the argument here is that the incumbent's utility increases when a member of the incumbent's party is in office in the second policy period.
} 
equilibrium is that it will expand the impunity region, thus allowing more opportunity for an opportunist incumbent to defect without repercussions. This occurs as the party is now less willing to remove the incumbent, as this would result in a larger decrease in the probability of electoral victory.

Although a decrease in challenger valence does not affect the structure of the equilibrium, it changes the borders between most of the regions. For an opportunist incumbent of middling valence, it lowers the border between full and partial accountability. Thus, she will be less likely to defect in the first period, but will also have a greater chance of renomination. Overall, this increases the expected utility of the incumbent. Finally, for a low-valence opportunist incumbent, a decrease in challenger valence will have no effect on incumbent welfare. The only change in behavior is that some incumbents who were formerly in the damnation region will now be in partial accountability. However, in partial accountability the opportunist incumbent is indifferent between defecting and not ${ }^{10}$ Even though an opportunist incumbent will now sometimes be accountable to the party in equilibrium, her expected utility is the same whether she defects or not.

\subsection{Repeated Interaction}

What if the parties and politicians repeatedly interacted over time? While a full treatment is beyond the scope of this paper, it is important to note that if all players have a common discount factor $\delta<1$ there will always be a level of polarization $\lambda$ high enough such that high-valence incumbents will defect with impunity.

\section{Case Studies}

Adding valence and importance to a simple electoral accountability framework results in a rich set of predictions on the relationship between parties and their politicians. This section presents case studies that conform with the theory. This does not prove the theory in any

\footnotetext{
${ }^{10}$ This is required to sustain the mixed strategy equilibrium in partial accountability.
} 
sense, rather it shows that the theory can be usefully applied to explain executive behavior.

\subsection{Impunity: Clinton and Welfare Reform}

Bill Clinton has often been described as the most talented, empathic and charismatic politicians of his generation. He was also seen by many as being primarily interested in his own reputation (see, e.g. Morris and McGann, 2004; Gartner, 2008). In the language of our model, he was an opportunist $\left(\theta_{I}=O\right)$ with high valence $\left(\Gamma_{I}>E\left(\Gamma_{C}\right)\right)$. Moreover, during Clinton's term in office, the two major U.S. parties were particularly polarized ( $\lambda$ was high: McCarty, Poole and Rosenthal, 2006). Thus, the theory predicts that he would defect from the party line and implement his own agenda in his first term, without repercussions from his party.

We focus here on welfare reform, where Clinton's agenda was different than his party's. As one commentator noted, "For many older Democrats, signing a Republican-drafted welfare bill would mark the president's betrayal of his party." (Hamilton, 2007, p. 601) Although one of Clinton's campaign promises was to "end welfare as we know it" Clinton, August 22, 2006), congressional Democrats "assumed Clinton talked about welfare largely as a rhetorical sop to conservative white voters" and considered it to be nothing more than "shrewd politics." (Harris, 2005, p. 231) Indeed, Clinton had vetoed two earlier welfare-reform bills "because [they] did too little to move people from welfare to work and too much to hurt poor people and their children." (Clinton, 2004, p. 694)

Yet, when faced with the third, largely similar, welfare reform bill, Clinton signed it into law despite the fact that one of his top advisors, George Stephanopoulos "had warned that 'signing the bill will cut the legs out from Democrats running against the extreme Gingrich Congress'," (Hamilton, 2007, p. 625) and that only one of his cabinet secretaries supported the signing (Haskins, 2006, p. 327). Clinton, knowing that his decision on the welfare reform bill would not affect his chances of re-election (Harris, 2005, p. 237; Haskins, 2006, p. 327), was swayed by the argument of his aid Bruce Reed: "Presidents since Lyndon Johnson had 
been attempting to do something big and bold about welfare and all had failed. Now Clinton could be the one to achieve major reform." (Haskins, 2006, p. 328, supported by Clinton, 2004, p. 720)

Many observers predicted that signing the welfare reform bill would provoke protests at the Democratic convention a week later (Harris, 2005, pp. 232-233; Hamilton, 2007, p. 626). Yet the theory predicts that Clinton's action would have no political consequences, and this prediction is borne out. There were no protests at the convention (Hamilton, 2007, p. 626) and even though two assistant secretaries at the Department of Health and Human Services resigned in a principled protest to the policy (Clinton, 2003, p. 370), they did so after the convention to minimize the political consequences to Clinton (Dionne, September 17, 1996. Edelman, 1997).

Note that the timing of the defection is consistent with the mechanism in our model. It is likely that if a party jettisoned the incumbent a week before her expected re-nomination, any replacement candidate would be unelectable (would have zero valence). Knowing this, the incumbent may find this to be an opportune time to defect from the party line as her valence, relative to that of a potential party challenger, is much larger than normal.

We now turn to British politics where, in contrast to U.S. politics, parties are considered by consensus to be quite strong and can change leadership quickly at any point in the electoral cycle.

\subsection{Impunity with Strong Parties: Blair and Iraq}

Despite the challenges of applying our theory to parliamentary democracies, where the executive is much less independent, the example of Tony Blair's Iraq policy fits impunity well: an executive with strong appeal to non-party voters champions a proposal opposed by his own party and is not dismissed.

In a good example of the fundamental tension we emphasize in our model, Tony Blair won leadership of the Labour party based on his appeal to the general electorate (high 
valence), and kept leadership even as his actions revealed greater and greater disagreements with his party. One Labour MP, when asked how he could support Blair for the leadership despite the fact that he would "jettison almost everything [the MP] stood for," replied, "Blair can put us back in power." (Stephens, 2004, p. 60) Further illustrating the tension between Labour and Blair, one commentator notes that Blair's opponents within Labour were relatively mute because "weakening Blair would mean weakening Labour." (Beckett and Hencke, 2005, p. 150)

Labour effectively traded ideological certainty for electoral success. A Gallup poll before former Labour leader John Smith's death in May 1994 indicated that 31\% of voters supported him for Prime Minister. Three months later, 45\% declared for Tony Blair, and "Labour commanded more widespread support than any party in Gallup's 57-year history." Abse, 1996, p. 10) Three years later, Blair led Labour to a landslide victory.

While many of Blair's early actions angered the Labour faithful, his biggest break with his party came over his decision to militarily support the U.S.'s invasion of Iraq in 2003. The vote to support Blair saw the biggest revolt in Labour history (up to that point) with 139 Labour MPs voting against the government, and three ministers resigning in protest (BBC, March 19, 2003). Moreover, Labour party members and local officials were generally seen as more opposed to Blair's position than Labour MPs. (Stothard, 2003, p. 52) Yet the party would not go as far as to imperil Blair's tenure in office, as he was still too valuable electorally.

Robin Cook, the most senior member to resign, noted in his resignation letter, his resignation speech and his memoirs that he did not intend his resignation to weaken Blair's position as Labour leader (Campbell and Stott, 2007, p. 679; Cook, 2003b). As Cook later wrote, "It would be a mistake...to exaggerate the disaffection with Tony in the party. The wider membership are appreciative of his electoral success." (Cook, 2003a, p. 303) As another commentator put it, "Labour MPs...love Tony Blair for his leadership in elections, and loath him for his leadership against Iraq."11 (Stothard, 2003, p. 82)

\footnotetext{
${ }^{11}$ Note that Blair's Iraq stance is unlikely to have helped him electorally even in the short run: a month
} 
The remainder of Blair's tenure as Prime Minister can also be understood in terms of the model: when his valence declined, he no longer had value to the party and was forced to resign. After Britain went to war against Iraq, Blair led Labour to a third consecutive victory in 2005 (albeit with a reduced majority, see Stephens, 2004, p. 239). However, as the occupation of Iraq stretched out and casualties mounted, Blair became increasingly unpopular, with the percentage of voters saying Blair could be trusted dropping from $63 \%$ when he was first elected, to $22 \% \cdot{ }^{12}$ As "[m]any Labour members were only half-hearted backers of Blair, content to support him as long as he was a winner, but not really liking him," eventually eight of his aides stepped down, pressuring him into setting a timetable for his resignation (Riddell, 2006, p. 197; Cowell, September 7, 2006).

\subsection{Damnation: Hayes, Arthur and Civil Service Reform}

When the incumbent has low valence and the election is important, our theory predicts parties will not re-nominate incumbents. Incumbents, knowing this, will defect from the party line. We illustrate this with the cases of Rutherford B. Hayes and Chester A. Arthur, two late $19^{\text {th }}$ century U.S. Presidents who defied their party - the Republicans - on civilservice reform and were not re-nominated.

It is somewhat surprising that low-valence politicians ever obtain office, as incumbents usually win elections because they had higher valence than their challengers, and thus higher valence than the average politician (Levitt and Wolfram, 1997; Ashworth, 2005; Daley and Snowberg, 2011). Indeed, Hayes should have lost the election of 1876-his opponent won the popular vote and would have won the electoral college as well if it weren't for several months of complicated maneuvering. In addition, Hayes secured the Republican nomination only because he was "everyone's second choice" (Dudley and Shiraev, 2008, p. 38). Arthur obtained the Presidency after his predecessor, James A. Garfield, was assassinated.

before the invasion, $81 \%$ of British voters did not support an invasion of Iraq without a second U.N. resolution, a resolution which never came (Travis, January 22, 2003).

${ }^{12}$ Figures are from Weiner (May 9, 2007). For a chart of Blair's popularity according to the survey agency MORI, see http://news.bbc.co.uk/2/hi/uk_news/politics/4717504.stm [retrieved October 19, 2009]. 
The parties during this time were remarkably similar in terms of espoused policy positions (Dudley and Shiraev, 2008, p. 50). However, elections were important as they determined whether party supporters would receive patronage and jobs. As evidence of this, the presidential campaign of 1876 is one of the dirtiest in U.S. history (Cummings, 2007).

Both Hayes and Arthur opposed their party on civil service reform, one of the main issues of the day (Sturgis, 2003, p. 11; Hoogenboom, 1961, pp. vii, 143). As an issue, civil-service reform works well with our theory as it clearly pits the interests of the President against that of his party (Schattschneider, 1942, p. 137-140). In addition to principled disagreements with the spoils system, executives complained about the burden of having to screen thousands of office seekers ${ }^{13}$ At the same time, civil service reform was an existential threat to late $19^{\text {th }}$ century political parties.

Hayes attacked the spoils system head-on, but ultimately failed due to the opposition of his party. He nominated several prominent civil-service reformers to his cabinet, while shunning "his competitiors for the nomination...their satellites...[and] members of Grant's cabinet," earning Hayes "the hostility of these powerful party leaders." (Hoogenboom, 1995, p. 296) Hayes also attempted (and lost several prominent battles over) reform of the New York Customhouse, which was responsible for $70 \%$ of the U.S.'s revenue at the time (Reeves, 1975, p. 63). Skowronek (1982, p. 56) declared Hayes's approach to civil-service reform atypical and "high minded." Hayes's policies lead his supporters to complain that his administration distributed offices "so as to discourage its friends and delight its enemies" (John Marshall Harlan quoted in Hoogenboom, 1995, p. 322) and that they were being killed off by Hayes's policies (Simpson, 1998, p. 215). Hayes's civil-service policies led many party leaders to feel they were "at war" with Hayes (Marcus, 1971, p. 29) and to talk of impeachment (Trefousse, 2002 , p. 70$)$.

In Arthur's first address to congress as President, he emphasized his support for civil service reform. Arthur pursued reform with a vigor that surprised many reformers - especially

\footnotetext{
${ }^{13}$ See Skowronek (1982, p. 56) for complaints from Hayes, Morgan (1969, pp. 161-162) for complaints from Garfield, and Doenecke (1981, p. 100) for complaints from Arthur.
} 
given his history as a notorious spoilsman. For example, after civil-service reform legislation was passed in 1882, reformers worried that he would pack the Civil Service Commission, tasked with enforcing the bill, with advocates of patronage. Instead, he appointed known reformers, who at the end of Arthur's term credited the "constant, firm and friendly support of the President" in accomplishing their goals (Reeves, 1975, p. 327) ${ }^{14}$ Arthur also defied his party by vetoing the pork-laden River and Harbors bill. His veto was quickly overridden by a congress controlled by his own party (Howe, 1935, pp. 170-171).

How could Hayes and Arthur afford to oppose their parties so blatantly? There is a simple answer: from the beginning they had little chance of re-nomination. Hayes, believing he couldn't win the presidency in 1876 (Williams, 1964), had promised after receiving the Republican nomination, to serve only one term if elected. However, even if he desired it, Hayes "could not be nominated again." (Doenecke, 1981, p. 17) Arthur similarly had no chance of re-nomination: he was never popular, and lost his core supporters (Howe, 1935, p. 215). Indeed, the New York Times, the newspaper of his faction, declared that, "Mr. Arthur cannot be elected." (quoted in Karabell, 2004 ${ }^{15}$

\section{Discussion}

Even when parties can provide strong incentives to their politicians - they can remove them from office at no cost - they may be unable to control their incumbents. In previous models, accountability to the representative voter fails because of asymmetric information about the effect of policies, or because the voter is insufficiently able to reward politicians. Yet we show that party control is significantly more difficult. Even with perfect information about politician actions and their consequences, party control can break down when valence and the importance of an election are taken into account.

\footnotetext{
${ }^{14}$ The most important victory for civil-service reformers during Arthur's term was the signing into law of the Pendleton Act. Scholars have attributed Arthur's signature to a variety of forces that are outside of our model, so we restrict attention to other indicators of Arthur's support for civil-service reform.

${ }^{15}$ Historians have speculated that Arthur's actions can be explained by the fact he was dying of Bright's disease. This is an extreme form of not expecting re-nomination.
} 
There are two main situations in which politicians defy their parties. The first occurs when popular incumbents know they are too electorally valuable to be punished by the party, and implement their own agenda with impunity. The second occurs when unpopular incumbents know they are too electorally weak to be kept on by the party, and with no way for the party to threaten or punish them, they defect from the party line. These mechanisms can provide an explanation for executive behavior in the U.S., Britain and elsewhere.

Although we have focused on the ability of parties to control an executive, we conclude by offering possible implications from our theory for the study of parties in legislatures.

First, the ability to deny re-nomination is similar - although somewhat stronger - to parties denying wayward legislators the "party brand", as in party cartel theory (Cox and McCubbins, 2005). This suggests that parties will, in certain political environments, lack the incentives to discipline wayward incumbents that are popular in their constituency. Thus, it may be misleading to gauge party strength by measuring how often politicians toe the party line, without controlling for other factors, such as valence and the importance of elections. ${ }^{16}$

Second, the theory suggests that it may be difficult to measure polarization between parties. When the parties are extremely polarized, elections are likely to be important to supporters and thus incumbents will rarely be accountable to the party. ${ }^{17}$ If this leads to incumbent legislators voting for more centrist policies, a measure of polarization based solely on votes may paradoxically indicate that a legislature is more highly polarized when, in fact, it is less highly polarized. However, the theory presented here also suggests that legislator turnover should increase when polarization increases. Examining patterns of legislator turnover, along with measures of polarization, can thus provide a check as to whether or not legislative scholars should concern themselves with this point.

\footnotetext{
${ }^{16}$ See Krehbiel (1993); Cox and McCubbins (1993); Patty (2008) for other perspectives on measuring party strength.

${ }^{17}$ Similarly, Fiorina, Abrams and Pope (2005) focus on a spatial model to explore the difficulty of measuring polarization in the electorate.
} 


\section{References}

Abse, Leo. 1996. The Man Behind the Smile: Tony Blair and the Politics of Perversion. London, UK: Robson Books.

Aldrich, John H. 1980. Before the Convention: Strategies and Choices in Presidential Nomination Campaigns. Chicago, IL: University of Chicago Press.

Ansolabehere, S. and J.M. Snyder. 2000. "Valence Politics and Equilibrium in Spatial Election Models." Public Choice 103(3):327-336.

Aragones, Enriqueta and Thomas R. Palfrey. 2004. "The Effect of Candidate Quality on Electoral Equilibrium: An Experimental Study." American Political Science Review 98(1):7790 .

Ashworth, Scott. 2005. "Reputational Dynamics and Political Careers." Journal of Law, Economics, and Organization 21(2):441-466.

Austen-Smith, David and Jeffrey Banks. 1989. Electoral Accountability and Incumbency. In Models of Strategic Choice in Politics, ed. Peter Ordeshook. Ann Arbor, MI: The University of Michigan Press pp. 121-150.

Banks, Jeffrey S. and Rangarajan K. Sundaram. 1993. Adverse Selection and Moral Hazard in a Repeated Elections Model. In Political Economy: Institutions, Competition, and Representation: Proceedings of the Seventh International Symposium in Economic Theory and Econometrics, ed. Barnett et. al. Cambridge University Press p. 295.

Barro, Robert J. 1973. "The Control of Politicians: An Economic Model." Public Choice 14(1):19-42.

BBC. March 19, 2003. "Blair Wins war Backing Amid Revolt." British Broadcasting Corporation, http://news.bbc.co.uk/2/hi/uk_news/politics/2862325.stm[retrieved October 19, 2009].

Beckett, Francis and David Hencke. 2005. The Survivor: Tony Blair in Peace and War. London, UK: Aurum.

Besley, Timothy. 2006. Principled Agents?: The Political Economy of Good Government. Oxford University Press.

Bowler, Shaun, David M. Farrell and Richard S. Katz. 1999. Party Discipline and Parliamentary Government. Ohio: Ohio State University Press.

Campbell, Alastair and Richard Stott. 2007. The Blair Years: The Alastair Campbell Diaries. New York, NY: Alfred A. Knopf.

Canes-Wrone, Brandice, Michael C. Herron and Kenneth W. Shotts. 2001. "Leadership and Pandering: A Theory of Executive Policymaking." American Journal of Political Science 45(3):532-550.

Clinton, Bill. 2004. My Life. New York: Alfred A. Knopf. 
Clinton, Bill. August 22, 2006. "How We Ended Welfare, Together." The New York Times p. A19.

Clinton, Hillary Rodham. 2003. Living History. New York: Simon \& Schuster.

Cohen, Marty, David Karol, Hans Noel and John Zaller. 2008. The Party Decides: Presidential Nominations Before and After Reform. Chicago, IL: University of Chicago Press.

Cook, Robin. 2003a. The Point of Departure. New York, NY: Simon \& Schuster.

Cook, Robin M.P. In Great Britain. Parliament. House of Commons. 2003b. Official Reports. Parliamentary Debates (Hansard). London: HMSO. March 17, 2003: Column 726-728.

Cooper, Alexandra and Michael C. Munger. 2000. "The (Un)Predictability of Presidential Primaries with many Candidates: Some Simulation Evidencepredictability of Primaries with Many Candidates: Simulation Evidence." Public Choice 103(3):337-355.

Cowell, Alan. September 7, 2006. "Pressure on Blair Mounts as 8 Aides Resign." The New York Times p. A10.

Cox, Gary W. and Mathew D. McCubbins. 1993. Legislative Leviathan. Berkeley, CA: University of California Press.

Cox, Gary W. and Mathew D. McCubbins. 2005. Setting the Agenda: Responsible Party Government in the US House of Representatives. Cambridge University Press.

Cummings, Joseph. 2007. Anything for a Vote. Philadelphia, PA: Quirk Books.

Daley, Brendan and Erik Snowberg. 2011. "A Multi-Dimensional Signaling Model of Campaign Finance." Journal of Law, Economics, and Organization forthcoming.

Dionne, E.J. September 17, 1996. "Resigning on Principle..." The Washington Post p. A15.

Doenecke, Justus D. 1981. The Presidencies of James A. Garfield and Chester A. Arthur. Lawrence, KS: The Regents Press of Kansas.

Dudley, Robert and Eric Shiraev. 2008. Counting Every Vote: The Most Contentious Elections in American History. Washington, D.C.: Potomac Books Inc.

Edelman, Peter. 1997. "The Worst Thing Bill Clinton has Done." The Atlantic Monthly 297(3):43-58.

Fearon, James D. 1999. Electoral Accountability and the Control of Politicians: Selecting Good Types versus Sanctioning Poor Performance. In Democracy, Accountability, and Representation, ed. Adam Przeworski, Bernard Manin and Susan C. Stokes. Cambridge University Press pp. 55-97.

Ferejohn, John. 1986. "Incumbent Performance and Electoral Control." Public Choice $50(1): 5-25$.

Fiorina, Morris P., Samuel J. Abrams and Jeremy C. Pope. 2005. Culture War? The Myth of a Polarized America. Pearson Longman. 
Fox, Justin and Kenneth W. Shotts. 2009. "Delegates or Trustees? A Theory of Political Accountability." The Journal of Politics 71(4):1225-1237.

Gartner, John D. 2008. In Search of Bill Clinton. New York: St. Martin's Press.

Groseclose, Tim. 2001. "A Model of Candidate Location when One Candidate Has a Valence Advantage." American Journal of Political Science 45(4):862-886.

Hamilton, Nigel. 2007. Bill Clinton: Mastering the Presidency. New York: Public Affairs.

Harris, John F. 2005. The Survivor: Bill Clinton in the White House. New York: Random House.

Haskins, Ron. 2006. Work over Welfare: The Inside Story of the 1996 Welfare Reform Law. Washington, D.C.: Brookings Institution Press.

Hirano, Shigeo, James M. Snyder and Michael M. Ting. 2009. "Distributive Politics with Primaries." Journal of Politics forthcoming.

Hoogenboom, Ari. 1961. Outlawing the Spoils: A History of the Civil Service Reform Movement, 1865-1883. Urbana, IL: University of Illinois Press.

Hoogenboom, Ari. 1995. Rutherford B. Hayes: Warrior $\&$ President. Lawrence, KS: University Press of Kansas.

Howe, George Frederick. 1935. Chester A. Arthur: A Quarter Century of Machine Politics. New York: Dodd, Mead and Company, Inc.

Karabell, Zachary. 2004. Chester Alan Arthur. New York: Times Books.

Krehbiel, Keith. 1993. 'Where's the Party?' British Journal of Political Science 23(2):235266.

Levitt, Steven D. and Catherine D. Wolfram. 1997. "Decomposing the Sources of Incumbency Advantage in the US House." Legislative Studies Quarterly 22(1):45-60.

Marcus, Robert D. 1971. Grand Old Party: Political Structure in the Gilded Age 1880-1896. New York, NY: Oxford University Press.

Maskin, Eric and Jean Tirole. 2004. "The Politician and the Judge: Accountability in Government." American Economic Review 94(4):1034-1054.

Mayhew, David R. 1974. Congress: The Electoral Connection. New Haven, Connecticut: Yale University Press.

McCarty, Nolan M., Keith T. Poole and Howard Rosenthal. 2006. Polarized America: The Dance of Ideology and Unequal Riches. Cambridge, MA: MIT Press.

Morgan, H. Wayne. 1969. From Hayes to McKinley: National Party Politics 1877-1896. Syracuse, NY: Syracuse University Press.

Morris, Dick and Eileen McGann. 2004. Because He Could. New York: Regan Books. 
Padró i Miquel, Gerard. 2007. "The Control of Politicians in Divided Societies: The Politics of Fear." Review of Economic Studies 74(4):1259-1274.

Patty, John. 2008. "Equilibrium Party Government." American Journal of Political Science 52(3):636-655.

Prat, Andrea. 2005. "The Wrong Kind of Transparency." American Economic Review $95(3): 862-877$.

Reeves, Thomas C. 1975. Gentleman Boss: The Life of Chester Alan Arthur. New York, NY: Alfred A. Knopf.

Rentoul, John. 2001. Tony Blair: Prime Minister. London, UK: Warner Books.

Riddell, Peter. 2006. The Unfulfilled Prime Minister: Tony Blair's Quest for a Legacy. London, UK: Politico's.

Riker, William H. 1982. Liberalism Against Populism: A Confrontation Between the Theory of Democracy and the Theory of Social Choice. San Francisco, CA: W.H. Freeman.

Rogoff, Kenneth. 1990. "Equilibrium Political Budget Cycles." The American Economic Review 80(1):21-36.

Schattschneider, E.E. 1942. Party Government. Holt, Rinehart and Whinston.

Serra, Giles. 2007. Why and When do Political Parties Adopt Primary Elections? A Theoretical and Comparative Study PhD thesis Harvard University, Department of Government Cambridge, MA: .

Serra, Giles. 2009. "Polarization of What? A Model of Elections with Endogenous Valence." mimeo. Nuffield College, Oxford.

Simpson, Brooks D. 1998. The Reconstruction Presidents. University Press of Kansas.

Skowronek, Stephen. 1982. Building a New American State: The Expansion of National Administrative Capacities, 1877-1920. Cambridge, UK: Cambridge University Press.

Snyder, James M. and Micheal M. Ting. 2008. "Interest Groups and the Electoral Control of Politicians." Journal of Public Economics 92(3-4):482-500.

Stephens, Philip. 2004. Tony Blair: The Making of a World Leader. New York, NY: Viking.

Stothard, Peter. 2003. Thirty Days: Tony Blair and the Test of History. New York, NY: HarperCollins Publishers.

Sturgis, Amy H. 2003. Presidents from Hayes through McKinley, 1877-1901. Westport, CT: Greenwood Press.

Travis, Alex. January 22, 2003. "Support for War Falls to New Low." The Guardian .

Trefousse, Hans L. 2002. Rutherford B. Hayes. New York, NY: Times Books. 
Weiner, Eric. May 9, 2007. "Blair Risked Much in Support of U.S.-U.K. Friendship." NPR.org, http://www.npr.org/templates/story/story.php?storyId=10102727] [retrieved October 19, 2009].

Williams, T. Harry. 1964. Hayes: Diary of a President 1875-1881, Covering the Disputed Election, the End of Reconstruction and the Beginning of Civil Service. New York, NY: David McKay Company, Inc. 


\section{Formal Derivation of Equilibrium}

We begin by asking when the party would prefer to re-nominate a known opportunist (that is, an incumbent who defected), rather than removing her. This will occur when $\Gamma_{I}(\lambda-1)>$ $E\left(\Gamma_{C}\right)\left(\lambda-\left(1-\pi_{C}\right)\right)$ or when:

$$
\Gamma_{I}>E\left(\Gamma_{C}\right) \frac{\lambda-\left(1-\pi_{C}\right)}{\lambda-1}
$$

This is the lower bound of the impunity region in Figure 2. In this region the party always re-nominates, and knowing this, the opportunist incumbent will always defect. A deviation by either the incumbent of the party clearly makes that player worse off so the equilibrium here is unique.

The next question is when the party will be content to keep the incumbent provided that they do not defect in the first policy period. When the incumbent never defects, then their posterior probability of being a loyalist will be the same as their prior probability, namely $\pi_{I}$. This will occur whenever $\Gamma_{I}\left(\lambda-\left(1-\pi_{I}\right)\right)>E\left(\Gamma_{C}\right)\left(\lambda-\left(1-\pi_{C}\right)\right)$ or when:

$$
\Gamma_{I}>E\left(\Gamma_{C}\right)
$$

as it is assumed that $\pi_{I}=\pi_{C}$. Note that the fraction in A.1 is larger than one, so A.2

does not imply A.1. That is, there is a region of values of $\Gamma_{I}$ and $\lambda$ such that the party will prefer to re-nominate the incumbent if she does not defect, but remove her if he does. The region bounded by $A .2$ and $A .1$ is thus the region of full accountability as defined in Figure 2. This is clearly optimal for the incumbent party.

It is optimal for the incumbent to not defect in the first period as long as $\eta<\Gamma_{I}$. By Assumption $\Gamma_{I}>E\left(\Gamma_{C}\right)$. Thus $\Gamma_{I}>\eta$. In order for it to be possible for the incumbent to mix between defecting and not defecting in equilibrium for these parameter values, it would need to be the case that the party sometimes re-nominates the incumbent when she defects. However, since A.1 is not satisfied, the party will never re-nominate the incumbent if she 
defects. Thus, the equilibrium is unique in this region as well.

In the region where $\Gamma_{I}$ is slightly less than $E\left(\Gamma_{C}\right)$ the party will be willing to re-nominate a politician with a slightly lower probability of re-election (than her expected replacement) provided that she has a slightly higher chance of being a loyalist. This will lead to the incumbent defecting with some probability less than one. Specifically, if $\sigma\left(\Gamma_{I}\right)$ is the probability that an opportunist incumbent defects, then this must be set such that the party is indifferent between re-nominating and removing an incumbent that does not defect. That is:

$$
\Gamma_{I}\left(\lambda-\left(1-\frac{\pi_{I}}{\left(1-\pi_{I}\right)\left(1-\sigma\left(\Gamma_{I}\right)\right)+\pi_{I}}\right)\right)=E\left(\Gamma_{C}\right)\left(\lambda-\left(1-\pi_{C}\right)\right)
$$

Thus, opportunist incumbents will defect with a probability given by:

$$
\sigma\left(\Gamma_{I}\right)=\frac{E\left(\Gamma_{C}\right)\left(\lambda-\left(1-\pi_{C}\right)\right)-\Gamma_{I}\left(\lambda-\left(1-\pi_{I}\right)\right)}{\left(1-\pi_{I}\right)\left(E\left(\Gamma_{C}\right)\left(\lambda-\left(1-\pi_{C}\right)\right)-\Gamma_{I}(\lambda-1)\right)}
$$

which is positive when $E\left(\Gamma_{C}\right)>\Gamma_{I}$. In order for opportunist incumbents to be indifferent between defecting and not defecting, they must be made indifferent by the party. Define $\rho\left(\Gamma_{I}\right)$ as the probability that the party re-nominates a politician that does not defect. The incumbent must be indifferent between defecting and being removed for sure, and not defecting and being re-nominated with some probability: $\eta=\rho\left(\Gamma_{I}\right) \Gamma_{I}$ or

$$
\rho\left(\Gamma_{I}\right)=\frac{\eta}{\Gamma_{I}}
$$

By finding when $\sigma\left(\Gamma_{I}\right)$ is zero and one we can establish the boundaries of the region of partial accountability. First, $\sigma\left(\Gamma_{I}\right)=0$ (full accountability) when $\Gamma_{I}=E\left(\Gamma_{C}\right)$ because $\pi_{C}=\pi_{I}$. This is the same boundary between full and partially accountably derived in A.2. Second, $\sigma\left(\Gamma_{I}\right)=1$ when

$$
\Gamma_{I}=E\left(\Gamma_{C}\right) \frac{\lambda-\left(1-\pi_{C}\right)}{\lambda}
$$

These are the upper and lower bounds, respectively, of the partial accountability region in 
Figure 2,

To see that the equilibrium is unique in this region, suppose the incumbent always defects. Then the party will know that a politician that does not defect is a loyalist for sure, and will re-nominate him. Knowing this, an opportunist incumbent will choose not to defect (as long as $\left.\Gamma_{I}>\eta\right)$ so always defect cannot be an equilibrium. Similarly, if the incumbent never defects then the posterior probability the incumbent is a loyalist is the same as the prior, and so the party will never re-nominate her. Given this, the opportunist incumbent would have preferred to defect, so this cannot be an equilibrium either. Therefore, in equilibrium in this region, the opportunist incumbent must mix between defecting and not defecting, and as everything is continuous the mixing probabilities in $(\mathrm{A} .3)$ and $(\mathrm{A} .4)$ are unique. Thus the equilibrium is unique in this region as well.

This final expression, for the boundary of the damnation region given in (A.5), can also be derived by asking when the party would fail to re-nominate the incumbent if they were sure that she was a loyalist. This would occur when $\lambda \Gamma_{I}<E\left(\Gamma_{C}\right)\left(\lambda-\left(1-\pi_{C}\right)\right)$. This resulting inequality defines the upper bound of the damnation region, where the party always removes incumbents. Incumbent opportunists know this will happen, and defect in their single policy period. Thus, the region bounded above by A.5 and below by zero is the damnation region identified in Figure 2, The behavior of the party, and the incumbent given the party's behavior is clearly optimal, so the equilibrium is unique in this region as well.

We conclude this description by asking when opportunist incumbents will prefer to defect even if the party could guarantee them re-nomination if they didn't. In this case they will prefer to defect when:

$$
\Gamma_{I}<\eta
$$

This is the temptation region in Figure 2. Note that a given set of parameter values $\left(\lambda, \Gamma_{I}\right)$ may be in one of the regions described above and in the temptation region. If the behavior in these two regions conflict then the opportunist incumbent follows their strategy under temptation: they always defect. In all regions but impunity, the party removes any politician 
that defects. When temptation overlaps full and partial accountability and the incumbent does not defect, they reveal themselves as a loyalist, and the party will always re-nominate them 18

${ }^{18}$ Note that this is insufficient incentive for the opportunists to try to imitate the loyalists. 


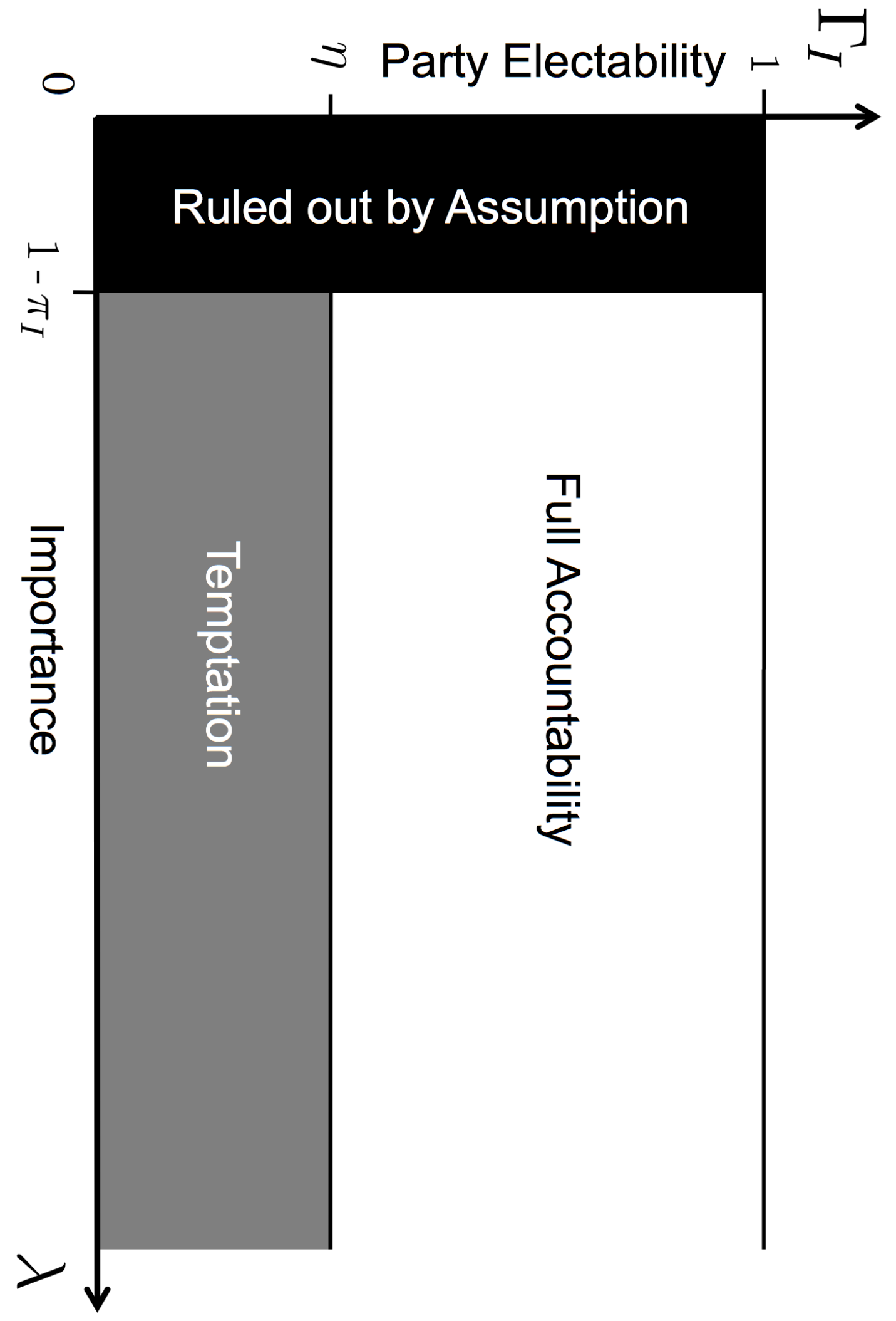

Figure 1: The equilibrium is simple when personal valence is not taken into account. 


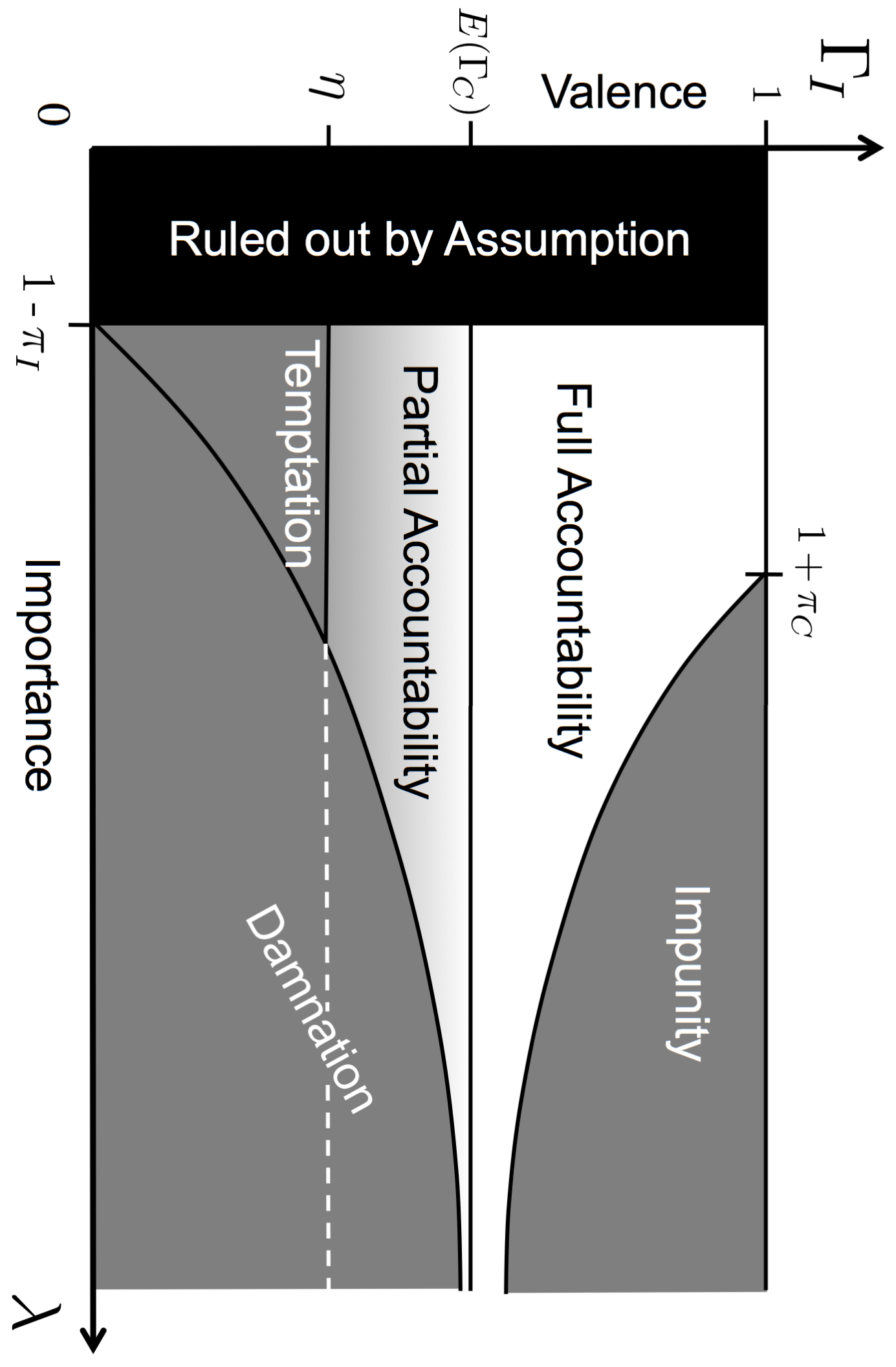

Figure 2: Equilibrium Characterization 


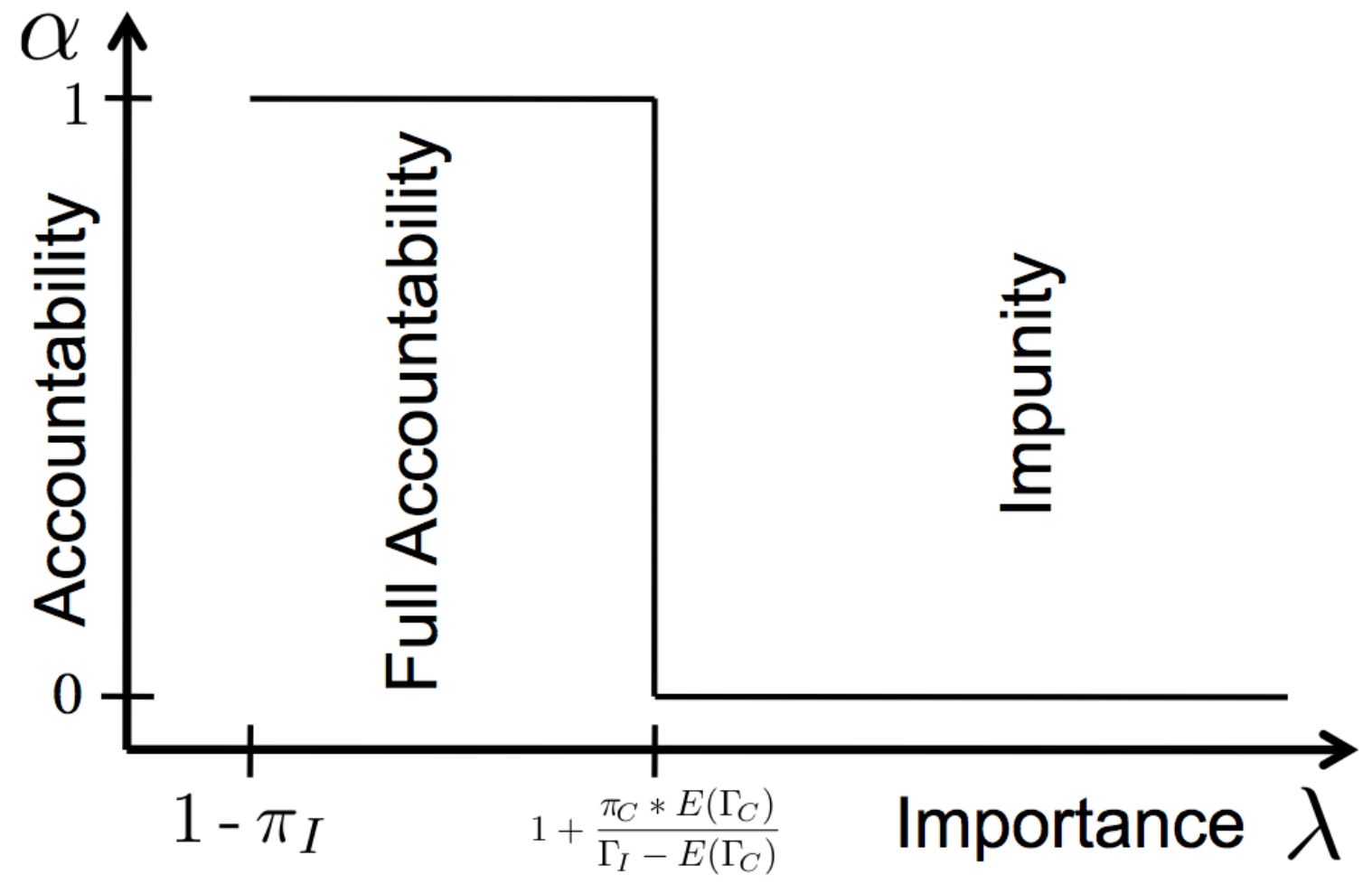

Panel A: $\Gamma_{I}>E\left(\Gamma_{C}\right)$

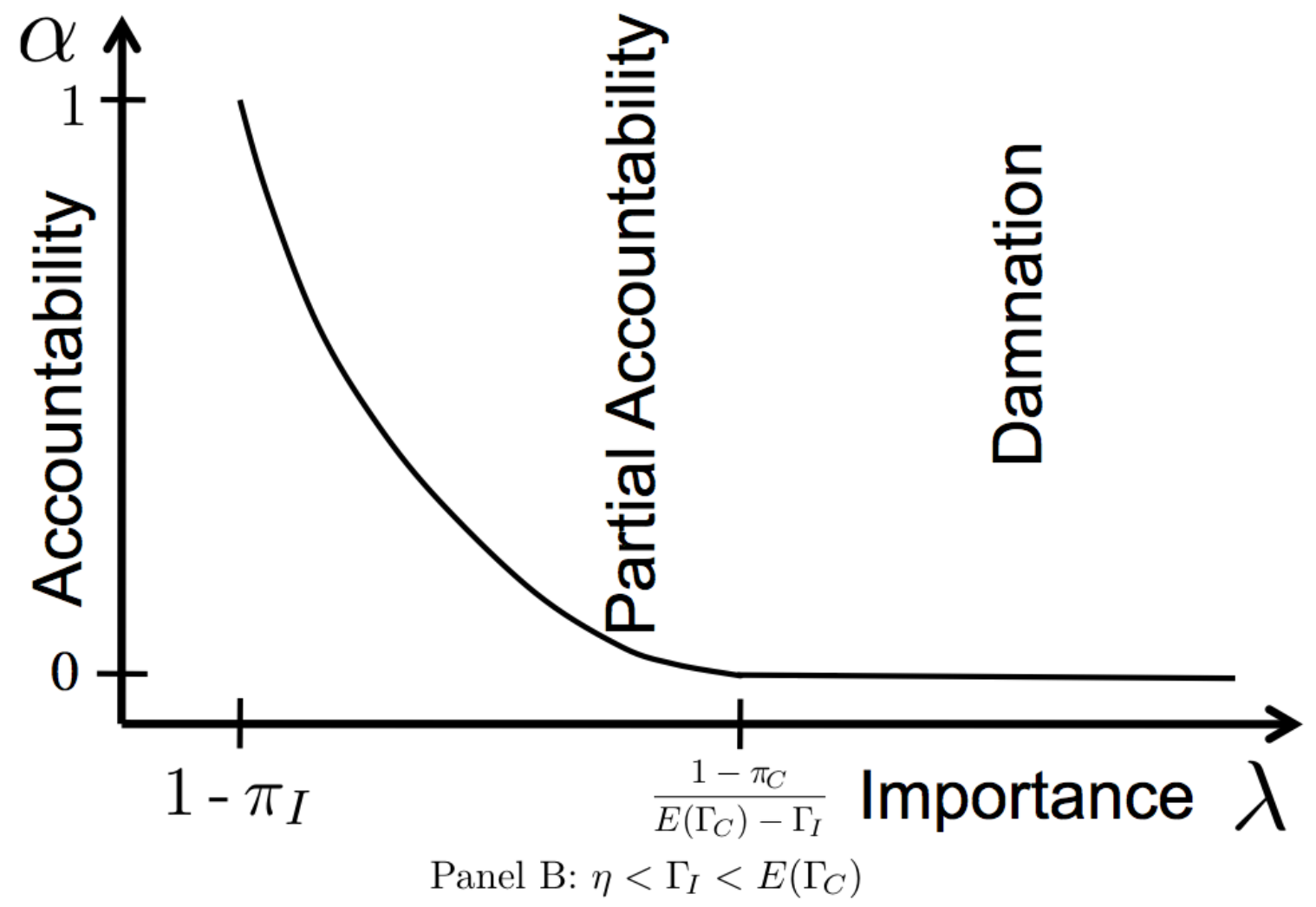

Figure 3: Increasing polarization decreases accountability to the party. 


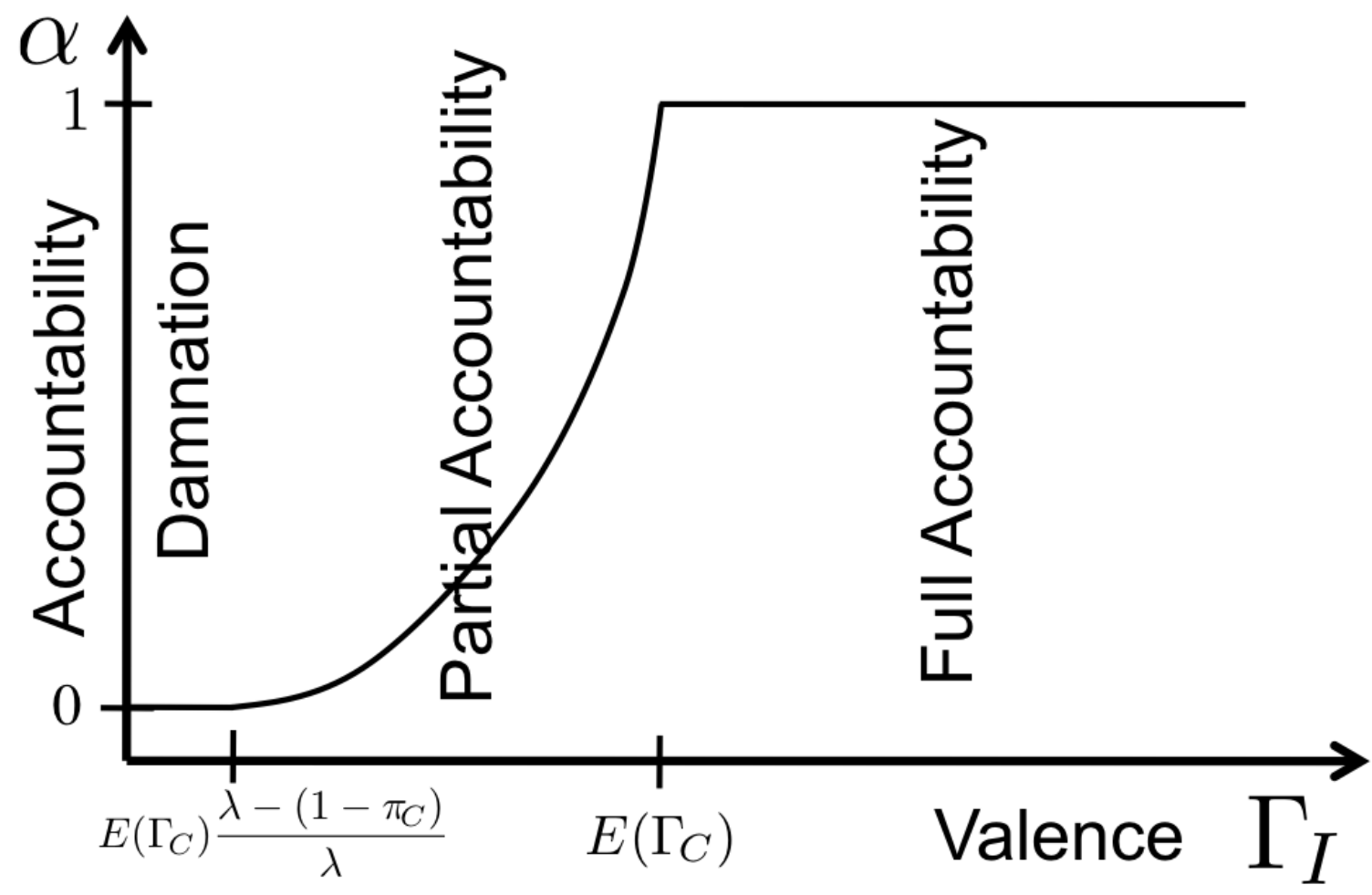

Panel A: $\frac{1-\pi_{C}}{E\left(\Gamma_{C}\right)-\eta}<\lambda<1+\pi_{C}$

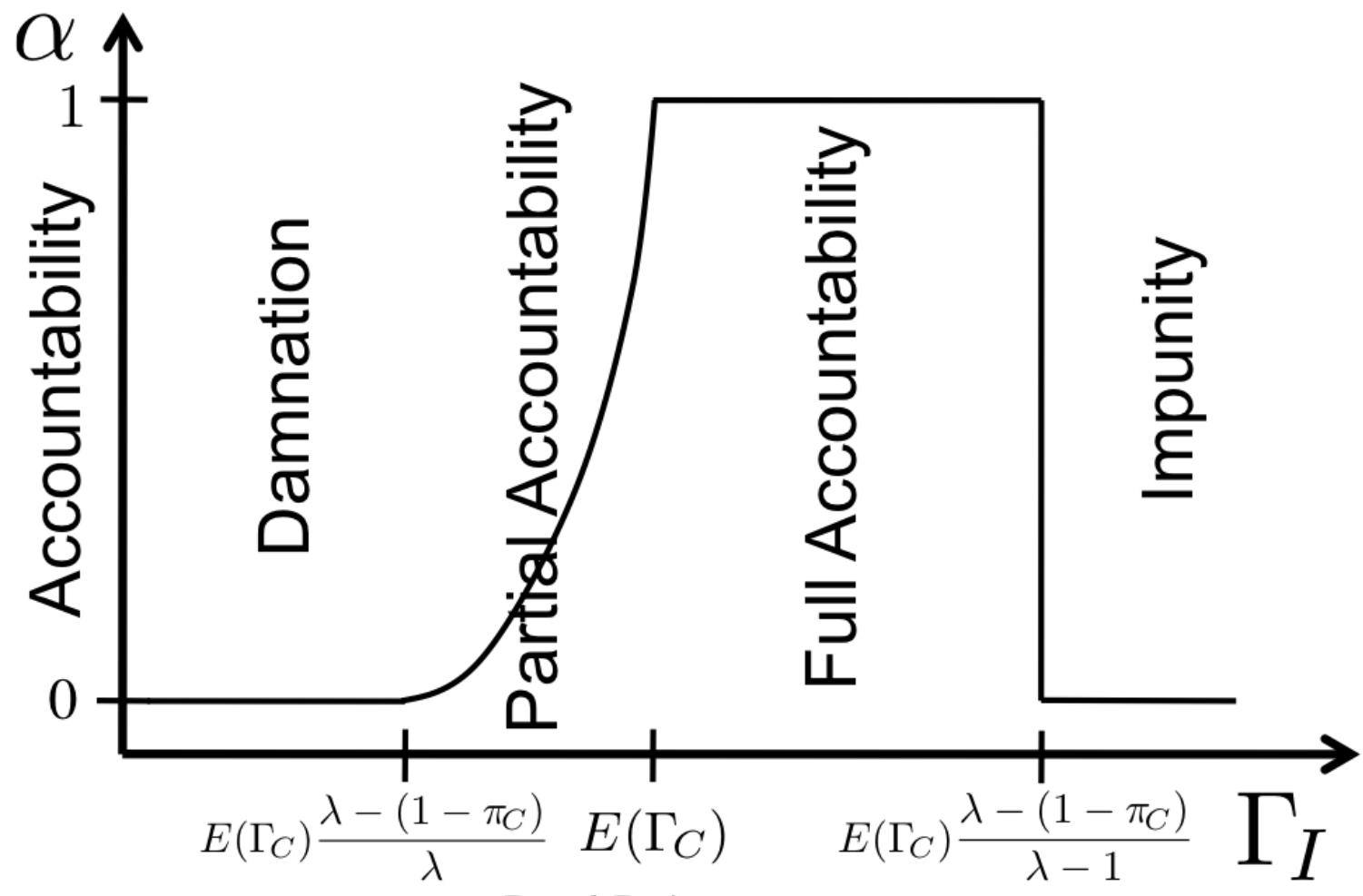

Panel B: $\lambda>1+\pi_{C}$

Figure 4: Increasing valence can have a non-monotonic effect on accountability to the party. 


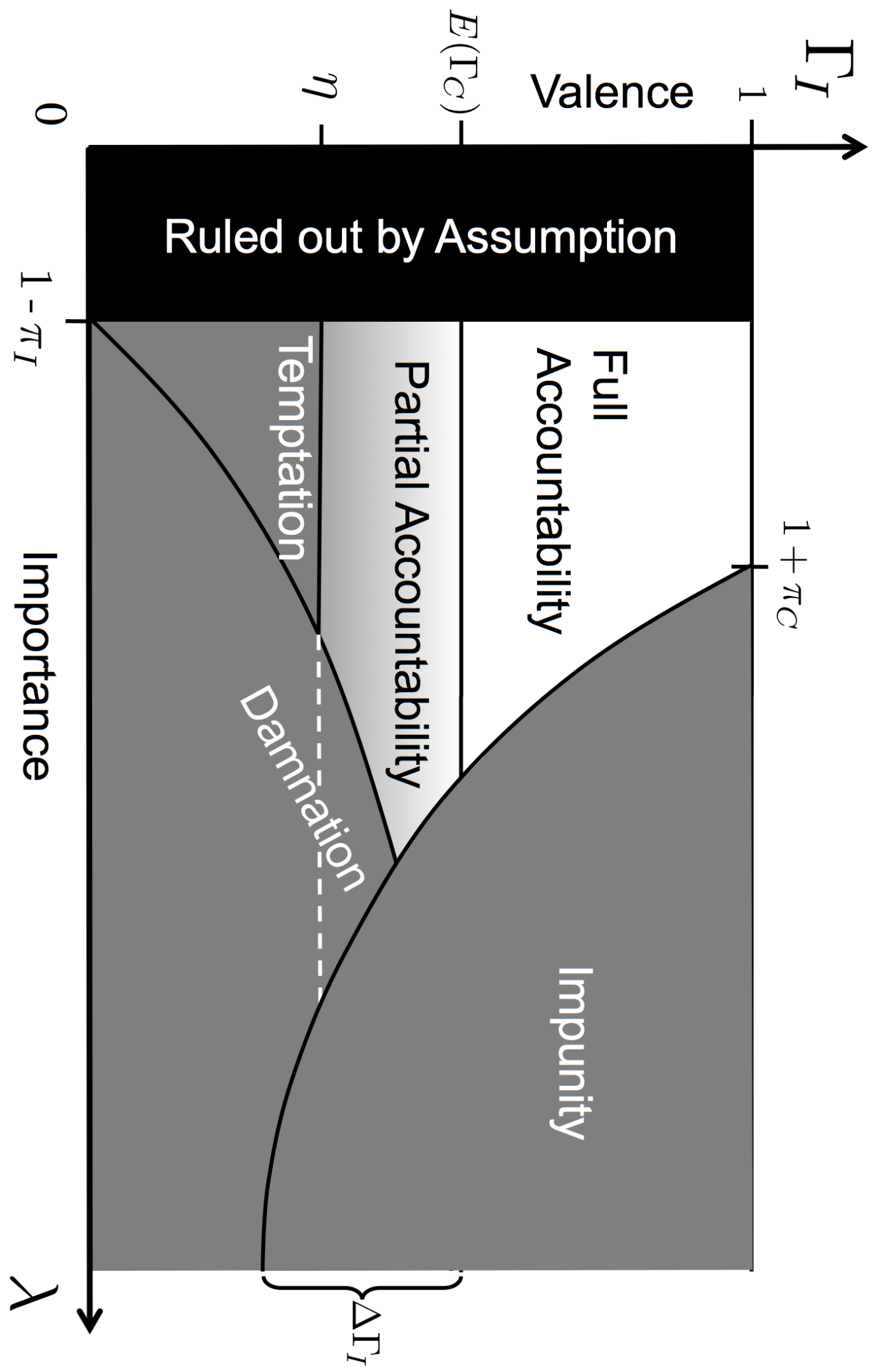

Figure 5: If centrist voters reward defection, it is more difficult to keep politicians accountable to the party. 


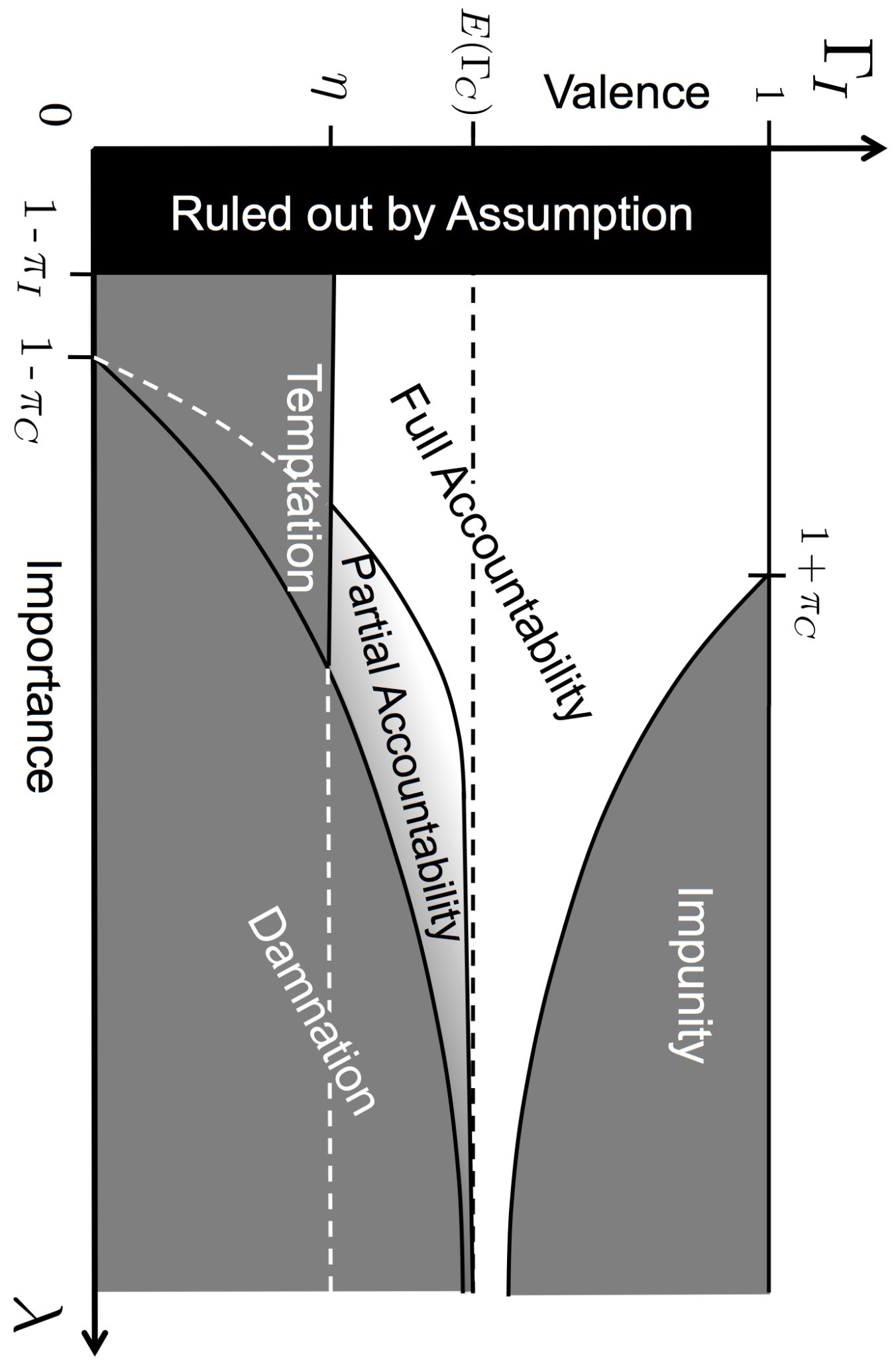

Figure 6: An incumbent with a higher probability of being a loyalist changes the equilibrium structure. 